\title{
Oxidative stability and quality of raw Saanen and Alpine goats milk
}

\author{
TEREZIJA SILVIJA MARENJAK', NINA POLJIČAK-MILAS'1, JASNA PIRŠLJIN², BLANKA \\ BEER LJUBIĆ ${ }^{2}$ nd SUZANA MILINKOVIĆ TUR ${ }^{2}$
}

'Department of Pathophysiology, Faculty of Veterinary Medicine University of Zagreb, Croatia, ${ }^{2}$ Department of Physiology and Radiobiology, Faculty of Veterinary Medicine University of Zagreb, Croatia

\section{Abstract}

The milk composition and concentration of thiobarbituric acid reactive substances (TBARS) and superoxide dismutase (SOD) activity in fresh and refrigerated raw goat milk of Saanen and Alpine breed at the breeding period were investigated. Low average milk fat, SNF and lactose content were determined in both breeds with no significant differences between breeds regarding the milk yield and milk composition. The significantly higher somatic cell count (SCC) was detected in Saanen goats. The SOD activity and TBARS concentration were significantly higher $14 \mathrm{~h}$ after the collection and cold storage in both breeds of dairy goats with no difference between the breeds. In the Alpine goats the TBARS concentration was negatively correlated with urea concentration, and in the milk of the Saanen goats the TBARS was positively correlated with proteins and SCC. The higher SCC in the Saanen goats may have caused higher production of secondary oxidative products catalysed by the enzyme superoxide dismutase from polymorphonuclear granulocytes present in the udder, or by some other enzymes that participate in oxidation of the milk constituents. The energy shortage and protein surplus in the diet of the dairy goats may have induced the higher degree of lipid mobilisation and a consequent increase of polyunsaturated fatty acids (PUFA) that are easily prone to oxidation and formation of the secondary oxidative products.

Keywords: goat, raw milk, milk components, peroxidation, quality

\section{Zusammenfassung}

\section{Oxidative Stabilität und Qualität der Rohmilch von Saanen- und Alpenziegen}

Untersucht wurde die Milchzusammensetzung, die TBARS-Konzentration (Thiobarbitursäurereaktive Substanzen) und die SOD-Aktivität (Superoxiddismutase) in frischer und gekühlter Rohmilch von Saanen- und Alpenziegen während der Fortpflanzungszeit. Zwischen beiden Rassen bestanden keine signifikanten Unterschiede bei der Milchleistung und der Milchzusammensetzung, wobei ein relativ niedriger Fett-, Laktosegehalt und ein niedriger Wert für die Trockensubstanz nachgewiesen wurden. Bei den Saanenziegen ergab sich ein höherer somatischer Zellgehalt (SCC). 14 Stunden nach der Milchgewinnung und Kühlhaltung waren in der Milch die TBARS-Konzentration und die SOD-Aktivität signifikant höher, wobei zwischen den Rassen keine Unterschiede ermittelt wurden. Eine negative Beziehung fand sich zwischen dem TBARS-Wert und dem Harnstoffgehalt bei den 
Alpenziegen, positiv war bei den Saanenziegen die Beziehung zwischen dem TBARS-Wert und dem Eiweiß- sowie SCC-Gehalt. Der höhere SCC-Gehalt war möglicherweise die Ursache für eine höhere Erzeugung von sekundären Oxidationsprodukten verursacht durch die Superoxiddismutase und den im Euter vorhandenen polymorphkernigen Granulozyten oder anderen Enzymen die an der Oxidation der Milchinhaltstoffe teilnehmen. Energiemangel und Eiweißüberschuss in der Ernährung von Milchziegen verursacht möglicherweise die höhere Lipidmobilisation und folglich die Erhöhung von mehrfach ungesättigten Fettsäuren welche leicht oxidieren und sekundäre Oxidationsprodukte bilden.

Schlüsselwörter: Ziege, Rohmilch, Milchinhaltsstoffe, Peroxidation, Qualität

\section{Introduction}

The health benefit of goat milk to human health has been proclaimed from the ancient times and has been extensively discussed but not scientifically improved in the matter under notice (HAENLEIN 2004)). The fatty acid composition in milk has drawn respectable attention, especially some fatty acids, such as caprylic and capric acid, and more recently conjugated linoleic acid (CLA) regarding their impact to human health (BADINGA and GREEN 2006, SORYAL et al. 2003, PFEUFFER 2001). The production and market expansion of goat's milk around the European Union shows the availability of goat's milk production in accordance with all regulatory standards (EUROPEAN COMMISION 1995, STRZALKOWSKA et al. 2006). It is questionable whether refrigerated raw goat's milk could retain high quality standards prior to processing in dairy industry. The milk constituents are greatly influenced by the breed, physiological stage (PETERS and LAES-FETBACK 1995, STRZALKOWSKA et al. 2004, GORECKI et al. 2004), stage of lactation (WOJTOWSKI et al. 2001, FAHR et al. 2001, STRZALKOWSKA et al. 2001), parity (STRZALKOWSKA et al. 2004), climate conditions (KIJORA et al. 2002) and nutrition (LEIBETSEDER 1996, KIJORA et al. 2002, FAHR et al. 2001, WALISIEVICZ-NIEBALSKA et al. 2004) of dairy goats. The unsaturated fatty acids (UFA) in raw milk may favour oxidative changes and oxidative reactions which may reduce the nutritive quality of milk and milk products (KONDYLI et al. 2005). Some indigenous enzymes are considered important for the oxidative stability of milk, such as superoxide dismutase (SOD) which inhibits the lipid oxidation (KORYCKA-DAHL and RICHARDSON 1979, LAMBERTSEN and CHRISTIANSEN 1997).

The main objective of the present research was to compare and evaluate the milk composition and oxidative stability of fresh and refrigerated milk in two breeds of dairy goats reared under the same farm conditions at the breeding season. The relationship between milk components, somatic cell count and oxidative stability of raw goat milk has been hypothized.

\section{Material and methods}

The research was conducted on two breeds of dairy goats, seven each of Saanen and Alpine goats, managed and kept on the same farm in an indoor/outdoor farming system. The farm was located in the inland part of Croatia, in Zagreb County where 21 breeders with 750 goats (male and female), mainly of the Alpine and Saanen breeds, were 
registered (CROATIAN AGRICULTURAL AGENCY 2006). At the experimental farm, the animals were kept indoors in a loose housing system, and outdoors, in a $6500 \mathrm{~m}^{2}$ paddock. In both breeds the feeding strategy was substantially the same. The daily ration consisted of mid-mature meadow hay, pasture and concentrate mixture consisted of $15 \%$ wheat bran, $10 \%$ barley grains, of $40 \%$ of corn grains, $15 \%$ soybean meal, $15 \%$ sunflower meal, 3\% Ovisan (Sano, GmbH) 1\% Multisan Nektar (Sano, GmbH), 1\% Camisan (Sano, $\mathrm{GmbH}$ ). Hay and water was offered ad libitum, and concentrate mixture twice daily, at the milking time. Both breeds were in the end of lactation (210 DIM). Alpine goats were in the fourth and the Saanen goats in the first parity. The goats were hand-milked at 7 a.m. and $7 \mathrm{p} . \mathrm{m}$. The milk production at the sampling periods was in average 1-2 litres/day $(\mathrm{I} / \mathrm{d})$ in both breeds. For the purpose of milk component analysis, $40 \mathrm{ml}$ of individual milk samples was collected at the morning milking period during the five days (70 milk samples) and transported in a cooler-box at $4^{\circ} \mathrm{C}$ to the laboratory. At the time of milk sampling (September 2006) the daily average air temperature was $22^{\circ} \mathrm{C}$, which was above the average annual temperature for that period of the year. The milk component analysis was performed $2 \mathrm{~h}$ after the milk sample collection, and measurement of SOD (superoxide dismutase) activity and TBARS (thiobarbituric acid reactive substances) concentration was performed, $2 \mathrm{~h}$ and $14 \mathrm{~h}$ after the collection and cold storage of samples in laboratory refrigerator at the $4^{\circ} \mathrm{C}$. The milk constituents protein, fat, lactose, and solids-non fat (SNF) were measured by automatic analyser (MilcoScan 4000, Denmark) and the somatic cell count (SCC) was determined by Fossomatic 5000 (Denmark). The milk urea concentration was measured by the colorimetric method using the commercial kit (Herbos Dijagnostika, Sisak, Croatia). Total SOD activity was measured using the commercial kit (RANSOD, »Randox«, Ireland). Determination of thiobarbituric acid reactive substances (TBARS) was performed according to the method of TROTTA et al. (1982). The absorption peak was measured at $532 \mathrm{~nm}$ and concentration was calculated using a molar extinction coefficient of $1.5 \cdot 10^{5}$ (PLACER et al. 1966). Total SOD activity and TBARS concentration were expressed per litter of milk.

The data were analysed using one-way MANOVA (Statistica 7.1, STATSOFT 2005). The results were presented as mean \pm standard deviation. The correlations between parameters were calculated. A multivariate test of significance was performed using the Wilks lambda test. The significance for all data was declared at $P<0.05$.

\section{Results and discussion}

The daily milk yield at the sampling period was lower from the average annual breed production (Table 1) with respect to parity which was, according the Annual Report of Croatian Agricultural Agency (CROATIAN AGRICULTURAL AGENCY 2006) $2.22 \mathrm{l} /$ day for the first parity in Saanen goats, and $2.38 \mathrm{l} / \mathrm{day}$, at the fourth parity in Alpine goats, respectively. Despite the difference in breed and parity, in the present study the milk components were not significantly different between two experimental groups of dairy goats (Table 1). The milk protein content was higher than 2.6\%, which is congruent with the results of KOZAČINSKI et al. (2004), but somewhat lower than reported by the CROATIAN AGRICULTURAL AGENCY (2006). The milk fat content was rather low in both breeds of dairy goats in the study, and lower than the average 
milk fat content in the Annual Report (CROATIAN AGRICULTURAL AGENCY 2006) and the result of KOZAČINSKI et al. (2004) and STRZALKOWSKA et al. (2007) (Table 1). Among other milk components, there is some evidence of higher deviation in milk fat content during the lactation cycle, especially due to dietary changes (PLOUMI et al. 1998, POLJČAK-MILAS and MARENJAK 2007, SANZ SAMPELAYO et al. 2007). In dairy goats, as well as in other ruminants, low milk fat syndrome might occur mostly as an effect of changes in rumen biohydrogenation processes. The essential strategy for prevention of milk fat depression, especially if fat supplements, fresh grass or oilseeds are present in the ruminant's diet, is adequate nutritional composition (WALISIEVICZ- NIEBALSKA et al. 2004). In the present study, an inverse relation of milk fat and milk protein, and milk urea and milk protein in the majority of experimental goats may reveal an energy shortage and protein surplus in the diet of dairy goats (Figure 1).

\section{Table 1}

Average milk composition and somatic cell count (SCC) in two breeds of dairy goats at the research (mean \pm standard deviation)

Milchzusammensetzung und Gehalt somatischer Zellen in der Milch der beiden untersuchten Populationen

\begin{tabular}{lcc}
\hline Milk components & Alpine & Saanen \\
\hline Fat, \% & $1.85 \pm 0.5$ & $2.10 \pm 0.23$ \\
Protein, \% & $2.62 \pm 0.34$ & $2.78 \pm 0.49$ \\
Lactose, \% & $4.02 \pm 0.18$ & $4.11 \pm 0.29$ \\
SNF, \% & $7.42 \pm 0.45$ & $7.66 \pm 0.65$ \\
Urea mmol/I & $3.61 \pm 0.14$ & $3.15 \pm 0.86$ \\
SCC, $\times 1000$ & $180.28 \pm 194.13^{\mathrm{a}}$ & $1122.43 \pm 1048.57^{\mathrm{b}}$ \\
Milk yield, I/d & $1.70 \pm 0.05$ & $1.80 \pm 0.10$ \\
\hline
\end{tabular}

SNF solids-non fat, SCC somatic cell count, Data with the different superscript ${ }^{\text {ab }}$ are significantly different at $P<0.05$.

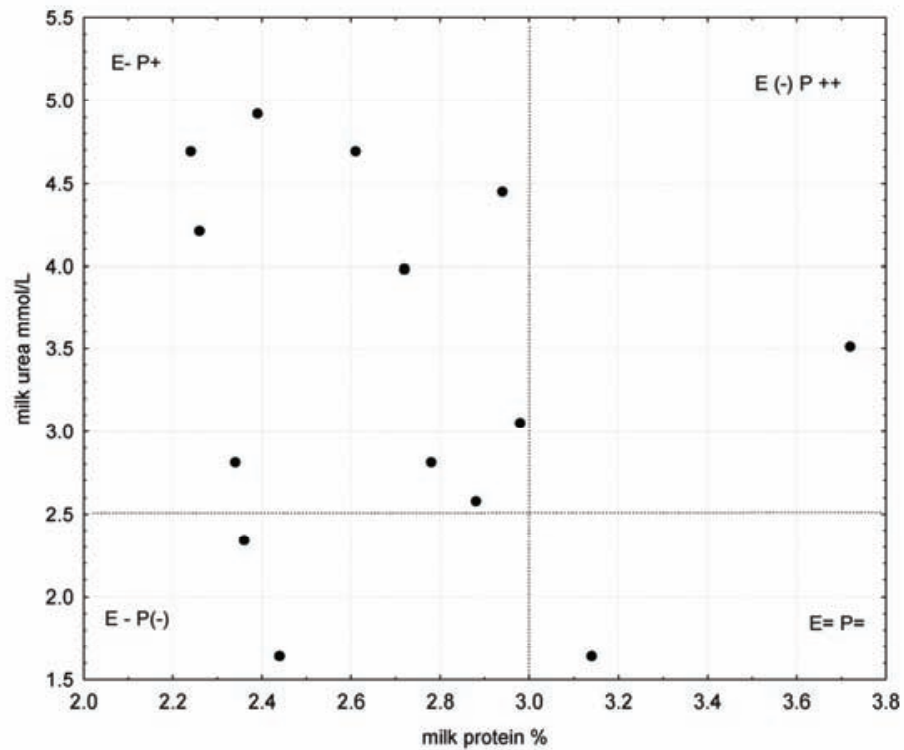

$\mathrm{E}-\mathrm{P}+$ energy shortage and protein surplus, $\mathrm{E}(-) \mathrm{P}++$ mild energy shortage and intensive protein surplus, $\mathrm{E}-\mathrm{P}(-)$ energy and mild protein shortage, $\mathrm{E}=\mathrm{P}=$ equable nutritional energy and protein

Figure 1

Milk protein and urea interrelationship

Beziehung zwischen Milchprotein und Milchharnstoff 
The lactose content was lower than in STRZALKOWSKA et al. (2004) and KOZAČINSKI et al. (2004) studies, and lower SNF content was also determined (Table 1). Usually, the lactose content positively correlates to milk yield and negatively correlates to lactation period according to VOUTSINAS et al. (1990) and PLOUMl et al. (1998) studies. The stage of lactation as a factor of difference between two the breeds could be omitted, but the stage of lactation could be taken into account, while lactose content is expected to be lowest in late lactation (VOUTSINAS et al. 1990). Furthermore, an insufficient energy supply in the ratio may cause a decrease in milk lactose content due to the lower supply in digestible carbohydrates that are an important source for the lactose synthesis in the mammary gland.

The concentration of milk urea ranged over 3.3-3.9 mmol/L, with lower average value for Saanen goats (Table 1), but was higher than reported by ARIELI et al. (2005). Milk urea is very often used for monitoring the nutritional status (energy/protein relation in the diet) in lactating dairy cows (MARENJAK et al. 2000) and there is some evidence of applicability in lactating ewes and goats (BED SANDOR NAGY et al. 2006, KIJORA et al. 2002). The higher milk urea concentration in the present research could be related to a protein surplus or concentration effect due to lower milk production. Elevated milk urea and losses in milk production could be related to improper balancing of rumen degradable proteins (RDP) and inefficient use of nitrogen, while goats are more efficient in nitrogen recycling in low crude protein diet than cows (PLOUMl et al. 1998). Certainly, other factors such as the environmental temperature and water consumption are very important factors that might influence the milk urea concentration and other milk constituents (SAHLU et al. 2004).

The average SCC (somatic cell count) in Alpine goats in the present study was lower than the allowable maximum level in most European countries. On the other hand, average SCC in Saanen goats was higher than recommended (Table 1) by Croatian and European Standards (EUROPEAN COMMISION 1995, OFFICIAL GAZZETTE 2000). However, in contrast to dairy cows, individual milk samples for evaluating total SCC in terms of detection of udder infection are less reliable for dairy goats (HAENLEIN 2002, STRZALKOWSKA et al. 2006). From the WILSON et al. study (1995), as much as $90 \%$ of the differences in goats' SCC were not due to intramammary infection. Many factors, other than intramammary infections, can influence the SCC in dairy goats, and as opposed to dairy cows, a higher allowable maximum SCC is permitted for raw goat milk. The stage of lactation usually influences the SCC in goats, but also age, level of milk production and breed may cause significant variations in SCC. HAENLEIN (2002) stated that hand milking may also elevate SCC. Moreover, the reproductive cycle and induction of oestrus were related to higher SCC, suggesting that the increase of SCC could be brought about by the oestrogen-induced proliferation and exfoliation of epithelial cells (MORONI et al. 2007) which might cause the average higher somatic cell count in Saanen goats in the present research. Therefore, it can be considered some other non-pathological factors that might have influenced the results of SCC analyses in the milk of Saanen goats in the present study, particularly nutrition, stage of lactation and the beginning of oestrus.

The results of SOD activity and TBARS concentration 2 and $14 \mathrm{~h}$ after collection and cold storage were presented in Table 2. The oxidative stability and formation of secondary oxidative products in milk samples were not significantly different between two breeds of 
dairy goats, although, to some extent, higher SOD activity and TBARS concentration were detected in the Saanen goats. The superoxide dismutase can serve as antioxidant agent in biological systems and foodstuffs, but under certain conditions might have peroxidative ability (KORYCKA-DAHL and RICHARDSON 1979). Determination of SOD activity and TBARS concentration in milk samples, after 14 hours of storage at $4{ }^{\circ} \mathrm{C}$, revealed a significant increase of secondary oxidative products and decrease of superoxide dismutase activity in both breeds of dairy goats, with rather lower formation of TBARS in the Saanen goats (Table 2).

Table 2

SOD activity and TBARS concentration in raw milk samples of Alpine and Saanen goats 2 and $14 \mathrm{~h}$ after collection (mean \pm standard deviation)

SOD-Aktivität und TBARS-Konzentration in der Rohmilch der Alpen- und Saanenziegen 2 und 14 Stunden nach der Milchgewinnung

\begin{tabular}{lcc}
\hline Breed & Alpine & Saanen \\
\hline SOD 2h, U/L & $3028.86 \pm 690.41^{\mathrm{a}}$ & $3199.14 \pm 2010.37^{\mathrm{a}}$ \\
SOD 14h, U/L & $2155.29 \pm 431.36^{\mathrm{b}}$ & $2486.27 \pm 1301.44^{\mathrm{b}}$ \\
TBARS 2h, $\mu \mathrm{mol} / \mathrm{L}$ & $2.25 \pm 0.86^{\mathrm{a}}$ & $2.73 \pm 1.46^{\mathrm{a}}$ \\
TBARS $14 \mathrm{~h}, \mu \mathrm{mol} / \mathrm{L}$ & $3.39 \pm 0.41^{\mathrm{b}}$ & $3.12 \pm 0.76^{\mathrm{b}}$ \\
\hline
\end{tabular}

SOD superoxide dismutase, TBARS thiobarbituric acid reactive substances, Different superscripts ${ }^{\mathrm{ab}}$ indicate differences of means at 2 and 14 hours being significant at $P<0.05$.

Off-flavours in milk and milk products are very often an effect of oxidation of fatty acids, linoleic acid especially, through the presence of superoxide dismutase (SOD) and hydrogen peroxide $\left(\mathrm{H}_{2} \mathrm{O}_{2}\right)$, therefore the oxidative stability of milk products is closely related to raw milk quality (KELLY and FOX 2006). On the other hand, SOD activity in fresh raw milk might have been dependent on the overall antioxidant status of the milk-producing animal. Higher oxidative stability in animal products may be expected under certain nutritional conditions such as natural or synthetic antioxidant agents, enzymes or minerals (SMET et al. 2005).

In the present research the TBARS concentration was very positively correlated to milk protein and SCC in the Saanen goats (Figure 2 and 3 ) and negatively correlated to milk urea concentration in the Alpine goats (Figure 4). The products of secondary oxidation might have originated from the SOD activity of polymorphonuclear granulocytes that are normally found in uninfected udders of dairy goats, but also are increased in infected ones, linearly with an increase of SCC. Therefore it could be presumed that positive correlation of SCC and TBARS concentration in Saanen goats was partly initiated from the hydrogen peroxide formation of neutrophile granulocytes, which might generate free radicals and oxidative changes of milk. The presence of numerous enzymes and higher SCC may be evidence of lower hygienic quality and technological properties of the raw milk. The highly negative correlation of TBARS and milk urea concentration in Alpine goats might be considered a result of nutritional imbalance and possible abounded lipid mobilisation to compensate the negative energy status of the experimental dairy goats. That could possibly affect the milk fatty acid composition and the higher percentage of PUFA in milk may encourage a higher degree of lipid peroxidation and consequently the formation of secondary oxidative products in milk. Low milk fat, higher milk urea concentration and high SCC in the Saanen goats, in particular, pointed to potential nutritional imbalance. A high grain diet might have been related to higher SCC in the Saanen goats, and lower production of milk fat and lactose in both experimental breeds of dairy goats. 
TBARS S $=-4.398+2.5659 \cdot$ protein $S$

Correlation: $r=0.86811$

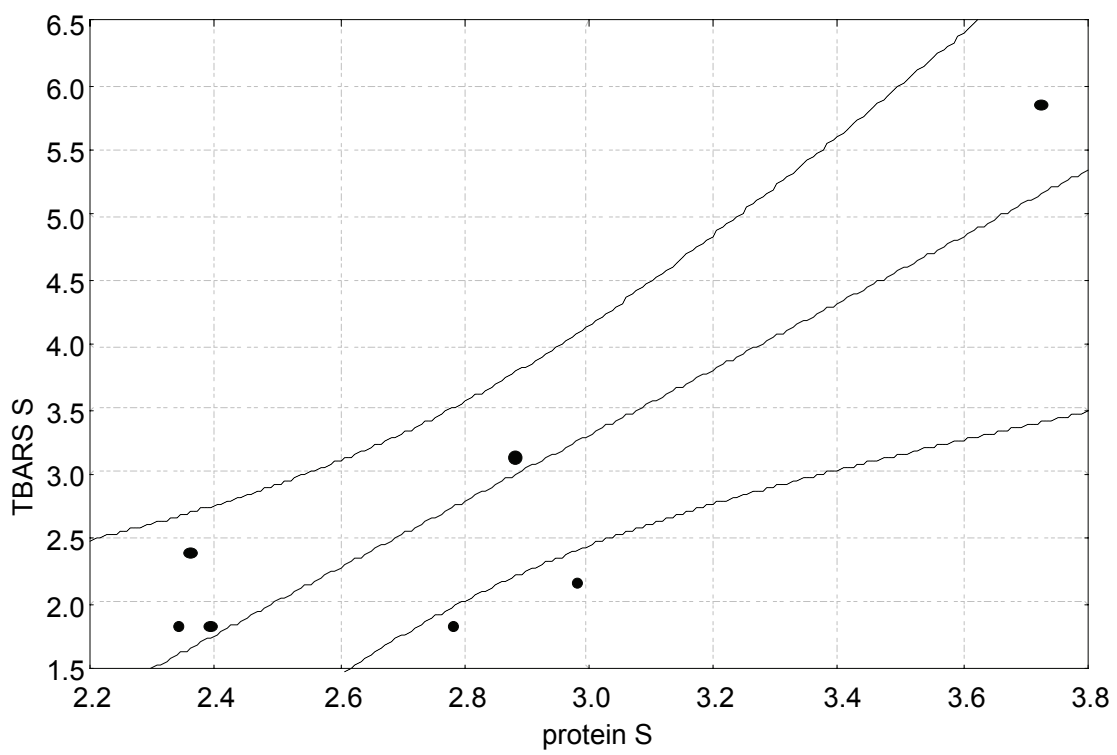

Figure 2

Milk protein and TBARS concentration in Sanen goats

Milchprotein und TBARS-Konzentration bei Saanen Ziegen

TBARS S $=1.9762+0.22 \mathrm{E}-3 \cdot \mathrm{SCC} S$

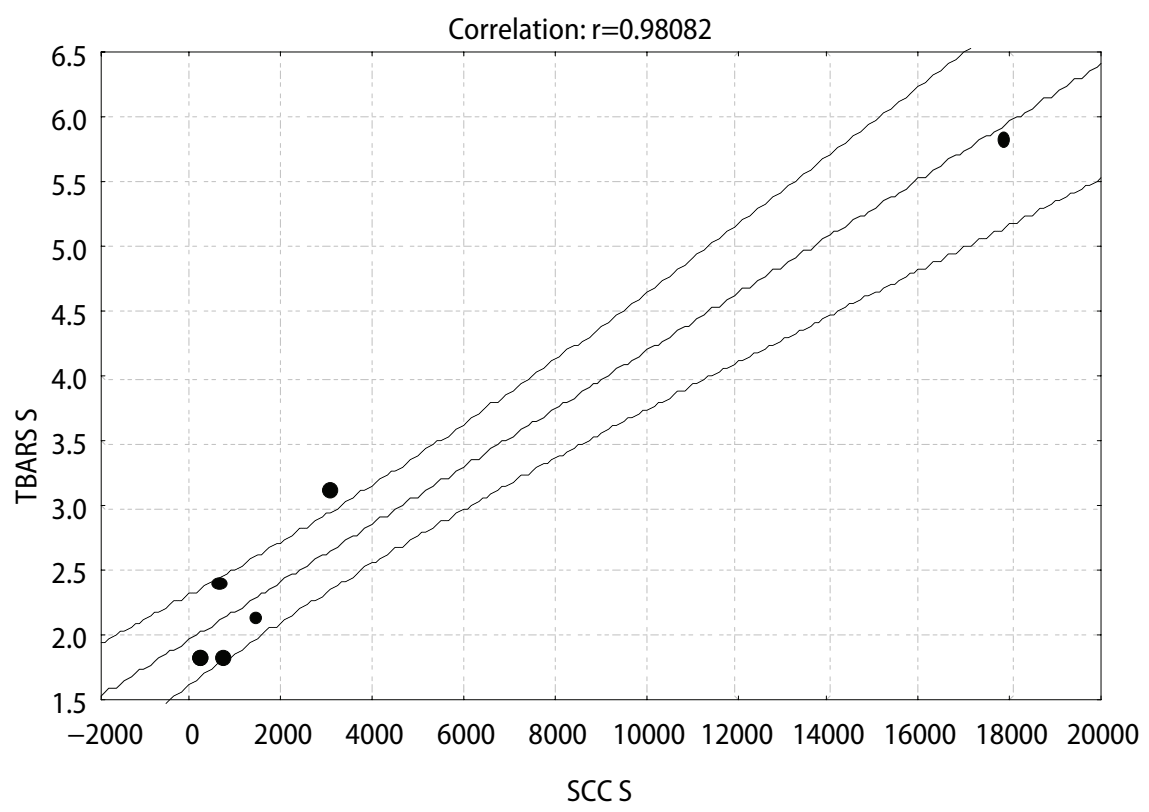

Figure 3

Somatic cell count and TBARS concentration in Saanen goats

SCC-Gehalt und TBARS-Konzentration bei Saanenziegen 


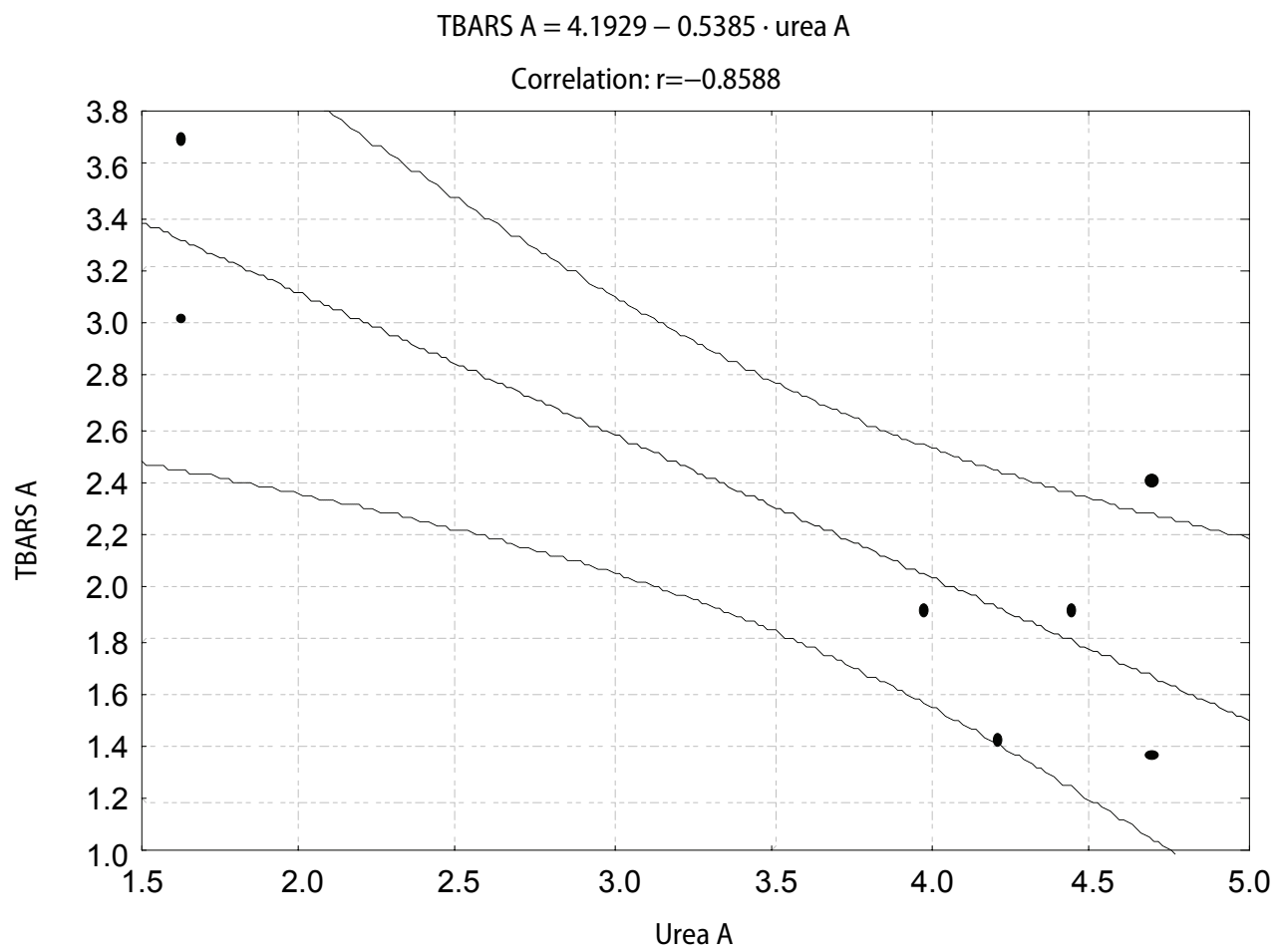

Figure 4

Milk urea and TBARS concentration in Alpine goats

Milchharnstoff und TBARS-Konzentration bei Alpenziegen

From the results of our study we may conclude, that the stage of lactation was a less important factor of difference in milk composition. We may also suspect that initiation of oestrus might have influenced the food intake and consequently a nutritional imbalance occurred. The initial oxidative stability of raw milk decreased in both breeds of dairy goats, after $14 \mathrm{~h}$ of cool storage, with more pronounced formation of secondary oxidative products in multiparous Alpine goats.

\section{References}

Arieli A, Sasson-Rath R, Zamwel S, Mabjeesh, SJ (2005) Effect of dietary protein and rumen degradable organic matter on milk production and efficiency in heat-stressed goats. Livest Prod Sci 96, 215-23

Badinga L, Green ES (2006) Physiological Properties of Conjugated Linoleic Acid and Implications for Human Health. Nutr Clin Pract 21,367-73

Bed Sandor Nagy Z, Nikodemusz E, Seregi J (2006) Milk urea and lactose as indicators of the protein and energy status in lactating ewes and goats. http://www.fao.org/regional/europe/PUB/RTS50/204.htm [last accessed 13.06.2007]

Croatian Agricultural Agency (2006) Annual Report. Goat breeding, 136

European Commision (1995) 95/41/EC

Fahr, R-D, Süss R, Schulz J, Lengerken von G (2001) A comparative study on factors affecting somatic cell counts in goat and sheep milk. Arch Tierz 44 SI, 288-99 [in German] 
Gorecki MT, Wojtowski J, Kaczmarek P, Dankow R, Cais-Sokolinska D, Nowak KW (2004) Concentrations of progesterone and $17 ß$-estradiol in blood and milk and those of natural inhibitors in milk of goats in various physiological stages. Arch Tierz $47 \mathrm{SI}, 90-6$

Haenlein GFW (2002) Relationship of somatic cell counts in goat milk to mastitis and productivity. Small Rumin Res 45, 163-78

Haenlein, GFW (2004) Goat milk in human nutrition. Small Rumin Res 51, 155-63

Kelly AL, Fox PF (2006) Indigenous proteolytic enzymes in milk. A brief overview of the present state of knowledge. Int Dairy J 16, 707-15

Kijora C, Peters K-J, Rexroth H, Chowdhury S (2002) Influence of energy level and dietary protein quality and quantity on the lactation performance of German Fawn Goats. Arch Tierz 45, 255-68 [in German]

Kondyli E, Andersen, ML, Skibisted LH (2005) Evaluation of oxidative stability of goat milk by Electron Spin Resonance Spectroscopy (ESR). Milchwiss 60, 271-4

Korycka-Dahl M, Richardson T (1979) Initiation of oxidative changes in foods. J Dairy Sci 20, 1181-98

Kozačinski L, Hadžiosmanović M, Cvrtila Ž, Majić T, Karadjole I (2004) Effect of lactation and number of somatic cells on the composition and quality of goat milk. Tierärztl Umschau 59, 453-63 [in German]

Lambertsen G, Christiansen N (1997) Milk fat: Nutrition and product development. Scan J Nutr 41 88-90

Leibetseder J (1996) Influence on the composition of animal fat by nutrition. Arch Tierz 39, 333-45 [in German]

Marenjak TS, Poljičak-Milas N, Turk R, Kampl B (2000) Possibility of metabolic control in cows by milk protein and urea determination. Vet Archiv 70, 251-7

Marenjak TS, Poljičak-Milas N, Zdelar-Tuk M (2006) A study of the effects of nutrition and seasonal, climatic factors on milk production and biochemical parameters in blood and milk of Simmental cows. Tierärztl Umschau 7, 357-62 [in German]

Moroni P, Pisoni G, Savoini G, Van Lier E, Acuna S, Damian JP, Meikle A (2007) Influence of estrus of dairy goats on somatic cell count, milk traits, and sex steroid receptors in the mammary gland. J Dairy Sci 90, 790-7

Official Gazzette of The Republic of Croatia (2000) 102

Peters K-J, Laes-Fettback C (1995) A comparative study of performance of Egyptian goat breeds. 1. Reproductive and dairy performance. Arch Tierz 38, 93-102

Pfeuffer M (2001) Physiologic effects of individual fatty acids in animal and human b ody, with particular attention to coronary heart disease risk modulation. Arch Tierz 44, 89-98

Placer ZA, Cushman LL, Connor Johnson B (1966) Estimation of product of lipid peroxidation (malonyldialdehyde) in biochemical systems. Anal Biochem 16, 359-64

Ploumi, K., Belibasaki, S., Triantaphyllidis, G (1998) Some factors affecting daily milk yield and composition in a flock of Chios ewes. Small Rumin Res 28, 89-92

Poljičak-Milas N, Marenjak TS (2007) Dietary supplement of the rumen protected methionine and milk yield in dairy goats. Arch Tierz 50, 273-8

Sahlu T, Goetsch AL, Luo J, Nsahlai IV, Moore JE, Galyean ML, Owens FN, Ferrell CL, Johnson ZB (2004) Nutrient requirements of goats: developed equations, other considerations and future research to improve them. Small Rumin Res 53, 191-219

Sanz Sampelayo MR, Chilliard Y, Schmidely PH, Boza J (2007) Influence of type of diet on the fat constituents of goat and sheep milk. Small Rumin Res 68, 42-63

StatSoft (2005) Statistica 7.1, USA

Smet K, Raes K, Huyghebaert G, Haak L, Arnouts S, De Smet S (2005) Influence of feed enriched with natural antioxidants on the oxidative stability of frozen broiler meat. 51st International Congress of Meat Science and Technology, Baltimore, Maryland USA, August 7-12, 758-63

Soryal KA, Zeng SS, Min BR, Har SP, Tesfai K (2003) Fatty acid profiles of goat milk and domiati cheese as afected by pasture feeding and stage of lactation. J Food Lipids 10, 219-36

Strzalkowska N, Bagnicka E, Jozwik A, Krzyzewski J (2006) Concentration of total cholesterol in milk of Polish White improved goats during the whole lactation. Arch Tierz $49 \mathrm{SI}, 166-73$

Strzalkowska N, Bagnicka E, Jozwik A, Krzyzewski J, Ryniewicz Z (2004) Chemical composition and some technological milk parameters of Polish White improved goats. Arch Tierz $47 \mathrm{SI}, 122-8$

Trotta R. J, Sullivan SG, Stern A (1982) Lipid peroxidation and hemoglobin degeneration in red blood ells exposed to t-butyl hydroperoxide. Biochem J 204, 405-15

Voutsinas L, Pappas C, Katsiari M (1990) The composition of Alpine goats' milk during lactation in Greece. J Dairy Res 57 41-51 
Walisiewicz-Niebalska W, Patkowska-Sokola B, Bodkowski R, Rozycki K (2004) The influence of linoleic acid and its isomers in goat diet on the oomposition of fatty acid in goat milk fat. Arch Tierz 47 $\mathrm{SI}, 103-7$

Wilson DJ, Stewart, KN Sears PM (1995) Effects of stage of lactation, production, parity and season on somatic cell counts in infected and uninfected dairy goats. Small Rumin Res 16, 165-9

Wojtowski J, Dankow R, Gut A, Pikull J, Slosarz P, Stanisz M, Steppa R (2001) Fat acid composition and cholesterol content of sheep and goat milk fat during lactation. Arch Tier 44 SI, 299-308 [in German]

Received 31 October 2007, accepted 11 June 2009.

Corresponding author:

TEREZIJA SILVIJA MARENJAK, PhD DVM

email:marenjak@vef.hr

Department of Pathophysiology, Faculty of Veterinary Medicine, University of Zagreb, Heinzelova 55, 10000 Zagreb, Croatia 